\title{
Electronic waste pollution and the COVID-19 pandemic
}

\author{
Deblina Dutta $^{1} \cdot$ Shashi Arya ${ }^{1,2} \cdot$ Sunil Kumar ${ }^{1,2} \cdot$ Eric Lichtfouse $^{3,4}(1)$
}

Published online: 27 July 2021

(c) The Author(s), under exclusive licence to Springer Nature Switzerland AG 2021

How waste will be managed in the future? Will humans be able to design zero-waste products and systems, or will there be a continuous urban mining to recycle waste in the circular economy? Here, new insights have been recently provided by the COVID-19 pandemic, which has somehow accelerated society evolution and thus provided a glimpse at what might happen in the future. In particular, lockdowns have suddenly amplified working from home with computers, increased the amount plastic and paper packages and decreased waste transportations. Here, we discuss issues of electronic waste (E-waste) pollution, toxicity and urban mining.

\section{Emergence of COVID-19}

After the Spanish flu in 1918-1920, the year 2020 will remain a milestone in the history of pandemics with the outbreak of the coronavirus disease 2019 (COVID-19, Goldstein 2020). This virus first appeared in December 2019 in Wuhan, China, and then waved all over the world within 2-3 months. On May 2, 2021, more than 150 million cases and 3 million deaths have been documented globally (WHO 2021). The coronavirus spreads through respiratory droplets, such as cough and sneeze, and through direct physical contact, e.g. by touching the affected person and then touching eyes, nose and mouth (WHO 2020). The virus also spreads the contamination through air and faecal-oral contact $(\mathrm{Qu}$ et al. 2020; Sun and Han 2020). In some countries, the

Sunil Kumar

s_kumar@neeri.res.in

1 CSIR- National Environmental Engineering Research Institute (CSIR-NEERI), Nehru Marg, Nagpur 440 020, India

2 Academy of Scientific and Innovative Research (AcSIR), Uttar Pradesh, Ghaziabad 201 002, India

3 Aix-Marseille Univ, CNRS, IRD, INRAE, CEREGE, 13100 Aix en Provence, France

4 State Key Laboratory of Multiphase Flow in Power Engineering, Xi' an Jiaotong University, Xi' an 710049, China presence of the coronavirus in the air has been directly correlated with the presence of a high concentration of particulate matter, thus resulting in an increased rate of mortality (He and Han 2020; Han et al. 2020). The symptoms include fever, cough and breathing problems, and patients may suffer from respiratory distress syndrome and dyspnoea in critical situations (Huang et al. 2020; Zhu et al. 2020). People with less immunity are more prone to COVID-19 diseases. The USA is one of the most affected countries, followed by Europe and South-East Asia. The global systems of waste treatment have been strongly impacted by the pandemic, as discussed in the following.

\section{Formal versus informal E-waste treatment}

E-waste generation has globally reached 53.6 million metric tons (Mt) in 2019 and is predicted to amplify approximately to 74 Mt by 2030 (Forti et al. 2020). Developed countries such as the USA, Europe and Australia are the major producers of E-waste. These E-wastes are then transported to developing countries such as India, China, Ghana, Pakistan, Nepal, Bhutan and Vietnam due to easy availability of open space for dumping and low-cost labour for recycling purposes (Arya and Kumar 2020a; Chi et al. 2011; Balde et al. 2017). In developing countries, most E-waste is handled improperly through unscientific methods, commonly termed 'backyard recycling' or 'informal recycling', whereas E-waste from major companies and government sectors is collected and processed professionally by formal recyclers (Arya and Kumar 2020b). E-waste handled by the formal recycling sector adheres to norms and legislations, whereas the informal sector is unaware of scientific methods and ignores norms and legislations. For instance, in Germany, only $17.4 \%$ of the total E-waste is recycled by the formal sector, the rest remaining undocumented and thus either stored, traded, dumped or recycled under lower standards (Forti et al. 2020). E-waste workers benefit from the informal sector for their livelihood, but they are exposed to severe health hazards (Dutta et al. 2016; Rautela et al. 2021). 
As a consequence, new regulations and recycling facilities have been proposed for proper management because a large quantity of E-waste is handled improperly by an uneducated population in the informal sector (Arya et al. 2021). The COVID-19 period has induced an almost complete shutdown of facilities and transportation (Kumar et al. 2020). Therefore, the E-waste chain, including collection and transportation, has been severely affected. For instance, the quantity and collection frequency of E-waste were affected, workers availability and safety decreased, and there was an increase in retrenchment (Sharma et al. 2020; Lord 2020; ILO 2020). The similarities between E-waste and the virus are explained in the following.

\section{E-waste as pollutant and vehicle for the virus}

E-waste is an heterogeneous mixture of metals, plastics, resins and glass. E-waste contains non-hazardous metals, e.g. iron and steel, hazardous metals such as lead, cadmium, chromium, mercury, arsenic, nickel, copper, cobalt and lithium, precious metals such as gold, silver, platinum and palladium, and rare earth metals such as neodymium, praseodymium, tantalum and indium (Wath et al. 2010; Dasgupta et al. 2014). E-waste also contains organic and inorganic chemicals which pollute the environment upon waste dumping. Since the viability of the coronavirus on metals and plastics is nearly five days (Khan et al. 2021), E-waste is very likely to have contributed to the contamination of a large population. This hypothesis is supported by the fact that the routes of both the virus and E-waste are similar, for example touching or breathing near a contaminated computer (Fig. 1). Moreover, the common health hazards caused by the coronavirus and E-waste are respiratory problems, damage to the nervous system, skin diseases, orthopaedic complications and cancer (Ramachandra and Saira 2004; Chen et al. 2011; Begum 2013; Cong et al. 2018; Decharat 2018; Seith et al. 2019; Davis and Garb 2019; Huo et al. 2019; Gu et al. 2019; Xu et al. 2020; Amoabeng Nti et al. 2020; Nithya et al. 2020).

\section{Urban mining}

The process of metal recovery from E-waste is known as 'urban mining' (Arya et al. 2021). Urban mining and recycling have potential to improve the country's economy and to decrease pollution and global warming. The main recycling methods start by a physical pretreatment, followed by pyrometallurgy, hydrometallurgy, electrometallurgy and biohydrometallurgy. E-waste contains more than 100 metals and materials which can be recycled and recovered (Cayumil et al. 2014; Kaya 2016; Garlapati 2016; Priya and Hait 2017;

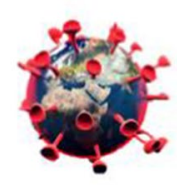

Coronavirus

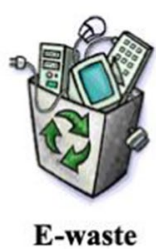

E-waste

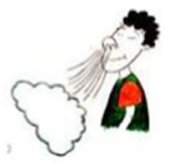

Inhalation
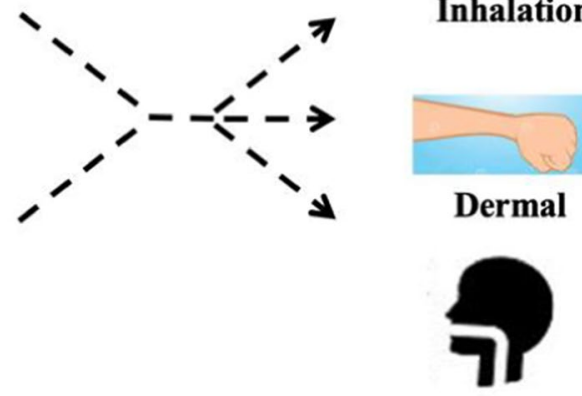

Ingestion
Fig. 1 The COVID-19 pandemic has induced an increase of electronic waste (E-waste). Both the virus and E-waste display similar transport routes and adverse effects such as respiratory problems and neurological damages. COVID-19: coronavirus disease 2019

Dutta et al. 2018; Barnwal and Dhawan 2020; Nshizirungu et al. 2020; Nithya et al. 2020).

\section{Circular concepts}

New concepts are required to cope up with the pandemic and to manage E-waste. Collection is a major issue in developing countries, calling for the set-up of more waste collection centres accessible to the public. To avoid viral transmission, the formal recycling sector has already taken precautions in handling E-waste such as storing waste a few days before handling. The formal recycling sector has also applied common precautions including sanitization, physical distancing and wearing masks, gloves and personal protective equipment. More generally, all sectors should plan the fate of all E-waste components after product use, and this should be enforced by laws and governments. Various mobile applications have been invented for easy collection of E-waste from home, yet such applications should be better publicized. All registered formal recyclers should increase their individual recycling capacities to combat the flood of E-waste generated during COVID-19 pandemic. More generally, in the future circular economy, both industrial producers and consumers should be responsible for the life of manufactured products.

\section{References}

Amoabeng Nti AA, Arko-Mensah J, Botwe PK, Dwomoh D, Kwarteng L, Takyi SA, Acquah AA, Tettey P, Basu N, Batterman S, Robins 
TG (2020) Effect of particulate matter exposure on respiratory health of e-waste workers at Agbogbloshie, Accra, Ghana. Int J Environ Res Public Health 17(9):E3042. https://doi.org/10.3390/ ijerph17093042

Arya S, Kumar S (2020a) Bioleaching: urban mining option to curb the menace of E-waste challenge. Bioengineered 11(1):640-660. https://doi.org/10.1080/21655979.2020.1775988

Arya S, Kumar S (2020b) E-waste in India at a glance: current trends, regulations, challenges and waste management strategies. J Clean Prod. https://doi.org/10.1016/j.jclepro.2020.122707

Arya S, Patel A, Kumar S, Pau-Loke SHOW (2021) Urban mining of obsolete computers by manual dismantling and waste printed circuit boards by chemical leaching and toxicity assessment of its waste residues. Environ Pollut. https://doi.org/10.1016/j.envpol. 2021.117033

Balde CP, Forti V, Gray V, Kuehr R, Stegmann P (2017) The Global E-Waste Monitor 2017. United Nations University. https://doi.org/ 10.1016/j.proci.2014.05.148

Barnwal A, Dhawan N (2020) Recycling of discarded mobile printed circuit boards for extraction of gold and copper. Sustain Mater Technol 25:e00164. https://doi.org/10.1016/j.susmat.2020.e00164

Begum KJ (2013) Electronic waste (E-Waste) management in India: a review. J Human Soc Sci 10(4):46-57. https://doi.org/10.9790/ 0837-1044657

Cayumil R, Khanna R, Ikram-Ul-Haq M, Rajarao R, Hill A, Sahajwalla V (2014) Generation of copper rich metallic phases from waste printed circuit boards. Waste Manage 34(10):1783-1792. https:// doi.org/10.1016/j.wasman.2014.05.004

Chen AK, Dietrich N, Huo X, Ho SM (2011) Developmental neurotoxicants in EWaste: an emerging health concern. Environ Health Perspect 119(4):431-438. https://doi.org/10.1289/ehp.1002452

Chi X, Streicher-Porte M, Wang MYL, Reuter MA (2011) Informal electronic waste recycling: a sector review with special focus on China. Waste Manage 31(4):731-742. https://doi.org/10.1016/j. wasman.2010.11.006

Cong X, Xu X, Xu L, Li M, Xu C, Qin Q, Huo X (2018) Elevated biomarkers of sympatho-adrenomedullary activity linked to e-waste air pollutant exposure in preschool children. Environ Int 115:117126. https://doi.org/10.1016/j.envint.2018.03.011

Dasgupta D, Debsarkar A, Chatterjee D, Gangopadhyay A (2014) E-Waste management in India: issues and concern. J Int Environ Appl 9(2):257-261

Davis JM, Garb Y (2019) A strong spatial association between e-waste burn sites and childhood lymphoma in the West Bank. Palestine Int J Cancer 144(3):470-475. https://doi.org/10.1002/ijc.31902

Decharat S (2018) Urinary mercury levels among workers in E-waste shops in Nakhon Si Thammarat Province. Thailand J Prev Med Public Health 51(4):196-204. https://doi.org/10.3961/jpmph.18. 049

Dutta D, Goel S, Hait J, Jha MK (2016) E-waste generation, management, utilization and recycling: A review. J Metal Mater Sci 58(3):89-98

Dutta D, Kumari A, Panda R, Soni J, Divika G, Goel S, Jha MK (2018) Close loop separation process for the recovery of $\mathrm{Co}, \mathrm{Cu}, \mathrm{Mn}, \mathrm{Fe}$ and Li from spent lithiumion batteries. J Separation Purification Technol 200:327-334

Forti V, Baldé CP, Kuehr R, Bel G (2020) The Global E-Waste Monitor 2020. Bonn/Geneva/Rotterdam.: flows and the circular economy potential. United Nations University (UNU)/United Nations Institute for Training and Research (UNITAR).

Garlapati VK (2016) E-Waste in India and developed countries: management, recycling, business and biotechnological initiatives. Renew Sustain Energy Rev 54:874-881. https://doi.org/10.1016/j. rser.2015.10.106
Goldstein JL (2020) The Spanish 1918 Flu and the COVID-19 disease: the art of remembering and foreshadowing pandemics. Cell 183(2):285-289

Gu W, Bai J, Yuan W, Ma E, Zhang C, Wang J (2019) Pollution analysis of soil polycyclic aromatic hydrocarbons from informal electronic waste dismantling areas in Xinqiao. China Waste Manag Res 37(4):394-401. https://doi.org/10.1177/0734242X19826369

Han J, Zhang X, He S, Jia P (2020) Can the coronavirus disease be transmitted from food? A review of evidence, risks, policies and knowledge gaps. Environ Chem Lett 19:5-16. https://doi.org/10. 1007/s10311-020-01101-x

He S, Han J (2020) Electrostatic fine particles emitted from laser printers as potential vectors for airborne transmission of COVID-19. Environ Chem Lett. https://doi.org/10.1007/s10311-020-01069-8

Huang C, Wang Y, Li X, Ren L, Zhao J, Hu Y, Zhang L, Fan G, Xu J, Gu X, Cheng Z (2020) Clinical features of patients infected with 2019 novel coronavirus in Wuhan. China the Lancet 395(10223):497-506

Huo X, Dai Y, Yang T, Zhang Y, Li M, Xu X (2019) Decreased erythrocyte CD44 and CD58 expression link e-waste $\mathrm{Pb}$ toxicity to changes in erythrocyte immunity in preschool children. Sci Total Environ 10:690-697. https://doi.org/10.1016/j.scitotenv

International Labour Organisation (ILO) Asian Development Bank (ADB) (2020) Tackling the COVID-19 youth employment crisis in Asia and the Pacific. https://www.ilo.org/wcmsp5/groups/ public/-asia/-robangkok/documents/publication/wcms_753369. pdf. Accessed on 23.02.2021.

Kaya M (2016) Recovery of metals and nonmetals from electronic waste by physical and chemical recycling processes. Waste Manage 57:64-90. https://doi.org/10.1016/j.wasman.2016.08.004

Khan AH, Tirth V, Fawzy M, Mahmoud AED, Khan NA, Ahmed S, Ali SS, Akram M, Hameed L, Islam S, Das G (2021) COVID19 transmission, vulnerability, persistence and nanotherapy: a review. Environmental Chemistry Letters 1-15.

Kumar A, Luthra S, Mangla SK, Kazançoğlu Y (2020) COVID-19 impact on sustainable production and operations management. Sustain Operat Comput 1:1-7. https://www.sciencedirect.com/ science/article/pii/S2666412720300015

Lord P (2020) Incentivising Employment during the COVID-19 Pandemic. Available at SSRN 3573176.

Nithya R, Sivasankari C, Thirunavukkarasu A (2020) Electronic waste generation, regulation and metal recovery: a review. Environ Chem Lett, 1-22. https://doi.org/10.1007/s10311-020-01111-9

Nshizirungu T, Rana M, Jo YT, Park JH (2020) Rapid leaching and recovery of valuable metals from Spent Lithium Ion Batteries (LIBs) via Environmentally Benign Subcritical Nickel-Containing Water over Chlorinated Polyvinyl Chloride. J Hazard Mater 122667. https://doi.org/10.1016/j.jhazmat.2020.122667

Priya A, Hait S (2017) Comparative assessment of metallurgical recovery of metals from electronic waste with special emphasis on bioleaching. Environ Sci Pollut R 24(8):6989-7008. https:// doi.org/10.1007/s11356-016-8313-6

Qu G, Li X, Hu L, Jiang G (2020) An imperative need for research on the role of environmental factors in transmission of novel coronavirus (COVID-19). Environ Sci Technol 54(7):3730-3732. https:// doi.org/10.1021/acs.est.0c01102

Ramachandra TV, Saira KV (2004) Environmentally Sound Options for E-Waste Management. Envis J Human Settlements, pp 1-10.

Rautela R, Arya S, Vishwakarma S, Kumar S (2021) E-waste management and its effects on the environment and human health. Sci Total Environ. https://doi.org/10.1016/j.scitotenv.2021.145623

Seith R, Arain AL, Nambunmee K, Adar SD, Neitzel RL (2019) Selfreported health and metal body burden in an electronic waste recycling community in Northeastern Thailand. J Occup Environ Med 61(11):905-909. https://doi.org/10.1097/JOM.0000000000 001697 
Sharma HB, Sarmah AK, Dubey B (2020) Hydrothermal carbonization of renewable waste biomass for solid biofuel production: a discussion on process mechanism, the influence of process parameters, environmental performance and fuel properties of hydrochar. Renew Sustain Energy Rev 123:109761.

Sun S, Han J (2020) Unflushable or missing toilet paper, the dilemma for developing communities during the COVID-19 episode. Environ Chem Lett. https://doi.org/10.1007/s10311-020-01064-z

Wath SB, Vaidya AN, Dutt PS, Chakrabarti T (2010) A roadmap for development of sustainable E-Waste Management System in India. Sci Total Environ 409(1):19-32. https://doi.org/10.1016/j. scitotenv.2010.09.030

World Health Organization (WHO) (2020) Advice on the use of masks in the context of COVID-19: interim guidance, 5 June 2020. https://apps.who.int/iris/handle/10665/332293. (Accessed on 18.02.2021)

World Health Organization (WHO) (2021) WHO Coronavirus Disease (COVID-19) Dashboard. https://covid19.who.int/?gclid=
Cj0KCQiAwMP9BRCzARIsAPWTJ_Hjhep5qv-AvH0RG2ssF AeoKmTIsrq-_W1wjzQSyh0gBXo1v1aK4r4aAgNwEALw_wcB (Accessed on 02.05.2021)

Xu L, Huo X, Liu Y, Zhang Y, Qin Q, Xu X (2020) Hearing loss risk and DNA methylation signatures in preschool children following lead and cadmium exposure from an electronic waste recycling area. Chemosphere 246:125829

Zhu H, Wei L, Niu P (2020) The novel coronavirus outbreak in Wuhan. China Global Health Research and Policy 5(1):1-3

Publisher's Note Springer Nature remains neutral with regard to jurisdictional claims in published maps and institutional affiliations. 